\title{
The influence of extraction method and conditions on the concentration of flavonoids in the extracts of rowanberries
}

\author{
Vaida Vaškeliené $\dot{x}^{*}$ \\ Rasa Šlinkšienè \\ ${ }^{1}$ Department of Physical \\ and Inorganic Chemistry, \\ Kaunas University of Technology, \\ 19 Radvilenu Road, \\ 50254 Kaunas, Lithuania
}

\begin{abstract}
For the extraction, rowanberries (collected in 2017 and 2018) and aqueous solutions of various concentrations of ethanol $(50 \%, 60 \%, 70 \%, 80 \%$ and $96 \%)$ in a ratio of 1:10 were used. Different types of extraction methods (extraction under static conditions, Soxhlet extraction and ultrasound assisted extraction) were tested. Using different types of extraction methods, it was found that irrespective of the method chosen when the concentration of ethanol increases, the concentration of total flavonoids also increases. Using collected rowanberries in 2017, the highest and similar numerical value of the concentration of total flavonoids was reached when an ultrasound bath was used $20 \mathrm{~min}$ for extraction $(0.512 \%)$ using a magnetic stirrer for $90 \mathrm{~min}(0.498 \%)$. In both cases, a $96 \%$ aqueous ethanol solution was used. The highest total concentration of flavonoids in the extracts of rowanberries collected in 2018 , obtained under static extraction conditions, using a $96 \%$ aqueous ethanol solution, was $0.525 \%$, in 2017 it was $0.418 \%$.
\end{abstract}

Keywords: rowanberries, flavonoids, extraction, concentration

\section{INTRODUCTION}

Rowan (Sorbus aucuparia L.) is a tree or a bush, usually planted as an ornamental tree, although it has medicinal characteristics. According to Olivier Raspé et al., flowers, fruits, leaves and bark can be used as medicinal plant materials. Usually, people harvest ripe fruits, which are drying out (as it is recommended, hanging in a well-ventilated room at about $60^{\circ} \mathrm{C}$ temperature), and then use them for therapeutic purposes as a source of vitamins or to prevent colds [1-3].

In medicinal plant encyclopaedias and scientific articles, authors state that rowanberries contain flavonoids, carotenoids, carbohydrates, organic acids (succinic, malic and citric), vitamins (C, E, K, $\mathrm{P})$, leaven, essential oils and minerals ( $\mathrm{Zn}, \mathrm{Fe}, \mathrm{Mg}$ and $\mathrm{Mn}$ compounds). The concentration of various

\footnotetext{
* Corresponding author. Email: vaida.vaskeliene@ktu.lt
}

active substances in fresh rowanberries were indicated: up to $65.0 \mathrm{mg} / 100 \mathrm{ml}$ of carotenoids; $44.5-$ $72.5 \mathrm{mg} / 100 \mathrm{ml}$ of vitamin C; $1.5-2.4 \mathrm{mg} / 100 \mathrm{ml}$ of iodine; $0.6-1.6 \mathrm{mg} / 100 \mathrm{ml}$ of vitamin $\mathrm{E} ; 4.0-7.0 \%$ of saccharides; up to $3.0 \%$ of sorbic acid and sorbitol; $0.13-2.1 \%$ of flavonoids; $1.9-2.6 \%$ of other organic acids; and up to $0.45 \%$ of yeast; essential oils; phospholipids; minerals [1-3].

According to Raspé et al., rowanberry pulp contains many minerals $(10.2 \%$ ash, $15.8 \mathrm{mg} / \mathrm{g}$ potassium, $17.7 \%$ sugars). The seeds are rich in crude proteins $(25.5 \%)$ and crude fat (16.5\%), phosphorus $(5.7 \mathrm{mg} / \mathrm{g})$ and calcium $(2.9 \mathrm{mg} / \mathrm{g})[3]$.

In Lithuania folk medicine rowan is used to treat cardiovascular diseases, for the treatment and prophylaxis of atherosclerosis, to stop bleeding, to reduce arterial blood pressure or as a source of vitamins. For prevention, the fruits are used against avitaminosis, they also improve appetite, promote urine 
output. Rowanberries are used to treat constipation, chronic diarrhea, and various liver and gall bladder diseases. Decoction or jam of dried fruit can be used to treat hemorrhoid and diarrhea. Fresh fruit juice is useful to drink when the acidity of the gastric juice is reduced. Cordials, which are made from flowers or leaves, promote urinary excretion, and cordials are recommended when complaining of painful menstruation, constipation, and for treatment of some kidney disease. In the case of periodontal disease in folk medicine, it is recommended to chew the berries and then spit them out. Flavonoids have antiinflammatory, anti-allergic, antiviral, anti-cancer, antioxidant and antimicrobial effects [1, 2, 4, 5,

To extract the active ingredients of rowanberries various extraction methods can be used. The most popular of these are maceration, infusion, decoction, tincture, hot continuous extraction (Soxhlet extractor), aqueous-alcoholic extraction by fermentation, percolation, counter-current extraction. More modern and fast-growing extraction methods include ultrasound extraction (sonication), microwave assisted extraction and supercritical fluid extraction. These advanced extraction methods have become popular as they have significantly reduced the duration of extraction. To use ultrasound for extraction is very useful when active substances are sensitive to high temperatures. The biggest advantage of using ultrasound is the possibility to choose and control the temperature mode when the solutions can be heated at $30-100^{\circ} \mathrm{C}$ or in order to avoid thermal damage of extracts [6, 7] no heating function might be used.

\section{EXPERIMENTAL}

Concentrations of carotenoids and flavonoids were determined by analysing the migration of the active substances from berries to extracts. The results of the total carotenoid concentration in extracts are presented in the report of the Project by Lithuanian Science Council (LMT) [8].

The following materials were used to determine total flavonoid concentrations: ethanol (96\% AB 'Stumbras'), acetic acid (99\% analytically pure, Reachim, Slovakia), aluminum (III) chloride hexahydrate (pure for analysis, 99.9\% purity, Reachim), rutin trihydrate (97\% purity, ThermoFisher, Germany), hexamethylenetetramine (purity $\geq 99.5 \%$, Sigma-Aldrich, South Korea).
Rowanberries were harvested after the first frost at the end of October in 2017 and in 2018. Berries were harvested in Kačerginè (Kaunas District) from the same branch of the same tree as the concentration of active ingredients in the berries would not be affected by external factors (sun, moisture, soil, air pollution, etc.) and would be possible to compare the results of different years. The collected berries were divided into two parts: one part was dried (at $60^{\circ} \mathrm{C}$ until the moisture content of the berries was constant and reached $8.4 \%)$ and the other part was frozen $\left(\right.$ at $\left.-18^{\circ} \mathrm{C}\right)$.

For the extraction, rowanberries and aqueous solutions of various concentrations of ethanol $(50 \%, 60 \%, 70 \%, 80 \%$ and $96 \%)$ were used in a ratio of $1: 10$. The rowanberries were dried in a convection oven at $60^{\circ} \mathrm{C}$ temperature until the moisture content of the berries was constant and reached $8.4 \%$.

The following methods were used for extractions:

1. The dried minced rowanberries were poured out with various concentrations $(50 \%, 60 \%, 70 \%$, $80 \%$ and $96 \%$ ) of aqueous ethanol solutions (AES). Extracts were kept under static conditions for 35 days at $22 \pm 1^{\circ} \mathrm{C}$, and analysed every 1-3 days.

2. Extracts were produced using magnetic and propeller stirrers (the same stirring speed is maintained) changing the stirring time (for $30 \mathrm{~min}$, $60 \mathrm{~min}$ and $90 \mathrm{~min}$ ).

3. Extracts were produced using a Soxhlet extractor (made of 3.3 borosilicate glass of upper grade). The complete apparatus includes a Dimroth condenser (DROG-100-001), an extractor (EXBG-100-001) and a flat bottom flask (BFFG250-001), a manufacturer in Spain. No less than 10 cycles.

4. Extraction in an ultrasound bath (VGT$2300 \mathrm{~B}, 40 \mathrm{kHz}$, made in China), the duration of which was $10 \mathrm{~min}, 20 \mathrm{~min}$ and $30 \mathrm{~min}$.

The extracts obtained by all these methods, were analysed by a UV-VIS spectrophotometer (T70+, an accuracy of absorption \pm 0.004 Abs, made in Great Britain). Absorption rates for the rowanberries extract and the absorption rates of the rutin trihydrate solution were measured using $10 \mathrm{~mm}$ thick quartz glass cuvettes at $407 \mathrm{~nm}$ in UV-VIS light. After the determination of the absorbance values of the test solutions of rowanberries and the absorption rate of the rutin trihydrate solution, the total 
flavonoid concentration (TFC) was calculated using the formula:

$$
T F C=\frac{m_{R} \cdot V_{M P M} \cdot D_{M P M} \cdot 100}{m_{M P M} \cdot D_{R} \cdot 50}, \% .
$$

Here $m_{R}$ is the mass of a rutin standard used to prepare the standard rutin solution, g; $V_{M P M}$ is the volume of ethanolic extract of the medicinal plant materials, ml; $D_{M P M}$ is the absorption rate of ethanolic extract (test solutions) of medicinal plant materials; $m_{M P M}$ is the dry mass of medicinal plant materials (berries) used to prepare the extract, $\mathrm{g} ; D_{R}$ is the absorbance of the standard rutin solution [9].

Electronic weighing scales were used for weighing (KERN PJL 360-3NM, $0.001 \mathrm{~g}$ accuracy, made in Germany). The moisture content of berries was determined by an electronic moisture analyser (KERN MLS, $0.001 \mathrm{~g}$ accuracy, made in Germany). Each sample of rowanberry extracts was analysed 3 times, then the arithmetic mean of the results was obtained and presented in the experiment as the final result of the analysis. To evaluate the reliability of the experimental results, a statistical evaluation of the experimental data was performed by calculating the sample dispersion $\left(S^{2}\right)$ and the standard deviation $\left(S_{x}\right)$ [10].

\section{RESULTS AND DISCUSSION}

A spectrophotometric method was chosen to determine total flavonoid concentration because it is fast, reliable and does not require a large amount of reagents. Using the UV-VIS spectrophotom- eter, the dependence of the total concentration of flavonoids on the extraction method was analysed: the way the berries were processed was changed (dried and frozen, also minced and not minced), as ethanol $(50 \%, 60 \%, 70 \%, 80 \%$ and $96 \%)$ was used as a solvent, and the temperature was maintained constant.

Extracts were produced using dried berries, which were harvested in 2018, and pouring them with $70 \%$ (Fig. 1a) and 96\% (Fig. 1 b) aqueous ethanol solutions (AES).

Using 70\% AES and dried minced and not minced berries for extraction, the obtained results showed that a higher total concentration of flavonoids was reached using minced berries (on 8 th day $0.374 \%$ TFC) than using not minced berries (on 8 th day $0.311 \%$ TFC). The results show that using minced and not minced berries for extraction the highest TFC is reached at the same time - on the 8th day. When the maximum concentration is reached, then TFC starts to decrease until on the 35th day the value is a little bit higher than on the 1st day of extraction. The decrease in the total concentration of flavonoids can be explained by the fact that when berries stay in an extract longer, ethanol breaks molecular bonds and/ or combines the flavonoid molecules to form new compounds whose absorption maximum moves to one or another part of the spectrum. Therefore, at a wavelength of $407 \mathrm{~nm}$, a lower absorption rate is recorded.

Dried minced and not minced berries poured with $96 \%$ ethanol, the TFC tendency of change remains the same as when $70 \%$ AES was used,

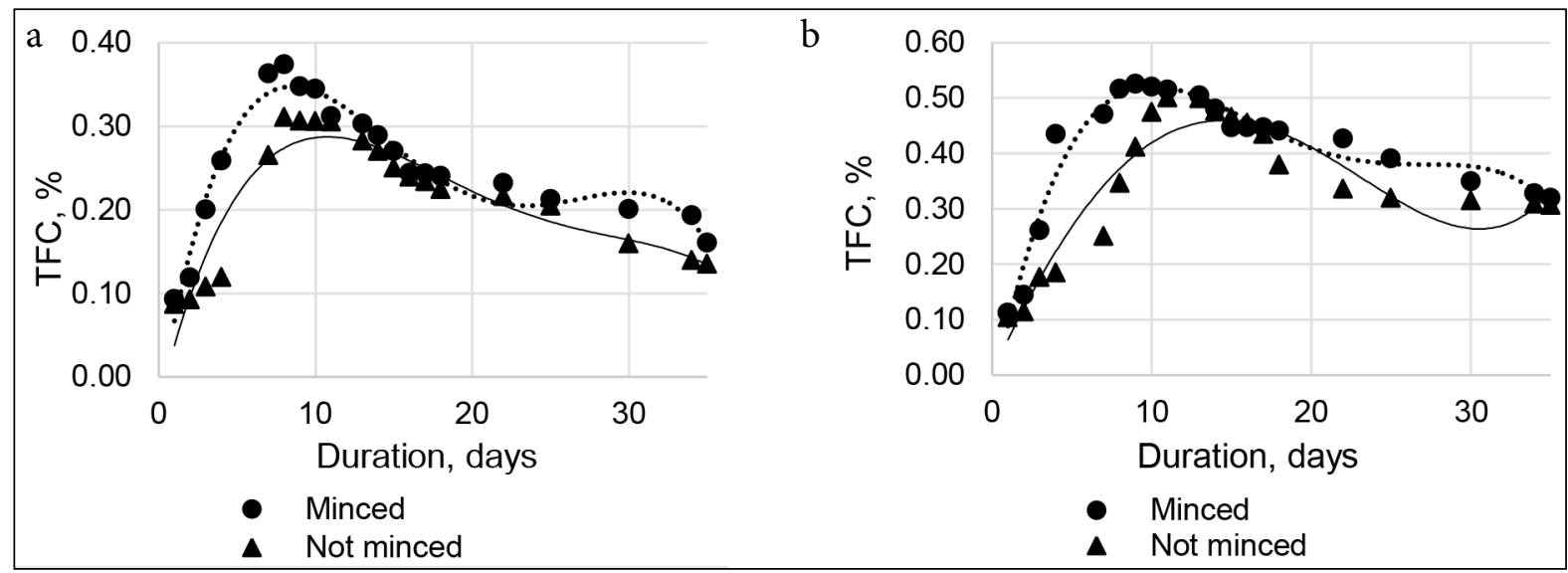

Fig. 1. TFC dependence on the process duration by using dried minced and not minced rowanberries poured out with various AES: $a-70 \%, b-96 \%$ 
however, the duration of receiving the maximum TFC time varies (Fig. 1 b). In the extract from dried minced berries and $96 \%$ ethanol, the highest TFC was reached on the 9th day $(0.525 \%)$, and in the extract from not minced berries on the 11th day $(0.500 \%)$.

The evaluation of the results obtained by extraction of dried berries with 70\% and 96\% AES show that only $96 \%$ AES was used to produce extracts from frozen berries (Fig. 2).

The graph above shows that the total concentration of flavonoids in the extract is higher when the berries are minced. The maximum TFC was reached on the 11th day of extraction when berries were minced $(0.235 \%)$ and on the 17 th day when they were not minced $(0.181 \%)$.

It can be concluded that in these cases the extracts containing minced berries have a higher TFC than not minced berries. The results can be explained: during the shredding of the berries, the surface area of the interaction is increased, which directly depends on the speed of the extraction process. In addition, the results are obtained with a better use of dried berries as the moisture content $(76.2 \%)$ of the frozen berries is 9 times higher than in the dried berries, therefore, the effect on alcohol is lower, despite the fact that the ratio of berries and solution is equal $=1: 10$.

In this work, most of the experiment was performed with similarly prepared dried minced berries harvested in 2017 by maintaining the same conditions for obtaining and analysing the extracts. In order to further determine the influence of the concentration of aqueous ethanol solutions on TFC, the concentration of AES has been ex- panded and $50-96 \%$ concentration solutions have been used as extraction solvents (Fig. 3).

The graph above (Fig. 3) shows the data that when the ethanol concentration increases, the concentration of flavonoids increases too. These results partly confirm the results obtained by Charpe [11], however, contradict V. Kothari et al. [ [7], who claimed that extraction of medicinal plant materials should be done using $70 \%$ aqueous ethanol solutions. In this experiment, the highest value of the total concentration of flavonoids was reached by using $96 \%$ ethanol $(0.418 \%)$, and the lowest by using $50 \%$ AES $(0.062 \%)$. In all cases, the highest total concentration of flavonoids in the extract was reached on the 9-11th days of extraction, and then TFC gradually decreased.

Having compared the Fig. 1 $1 \mathrm{~b}$ and Fig. 3 d graphics, it is seen that in the extract produced with the berries collected in 2018, which were dried minced and poured with $96 \%$ ethanol, the maximum obtained TFC value is greater than in the extract of the berries collected in 2017 and similarly prepared by maintaining the same conditions. However, as can be expected, it becomes clear that though the berries are picked from the same branch of the same tree, the annual climatic conditions affected the concentration of the active ingredients in the berries. Therefore, it cannot be said that the TFC are constant and that the results obtained must be repeated for several consecutive years.

In order to shorten the extraction time, it was decided to produce the extracts by stirring. In the absence of data which stirrer is more effective (magnetic or propeller when the same stirring

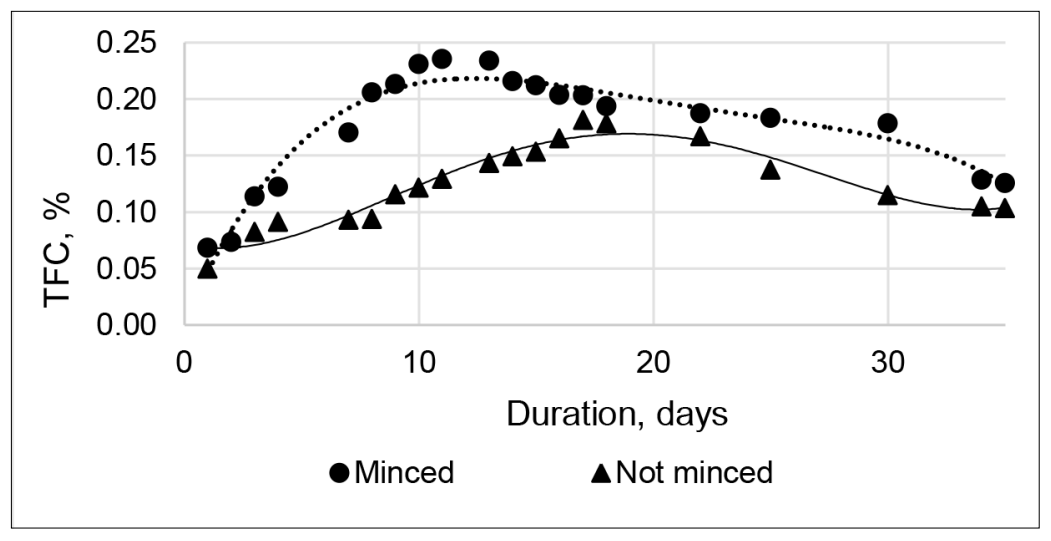

Fig. 2. TFC dependence on the process duration by using frozen minced and not minced rowanberries (2018 year) poured out with $96 \%$ ethanol 


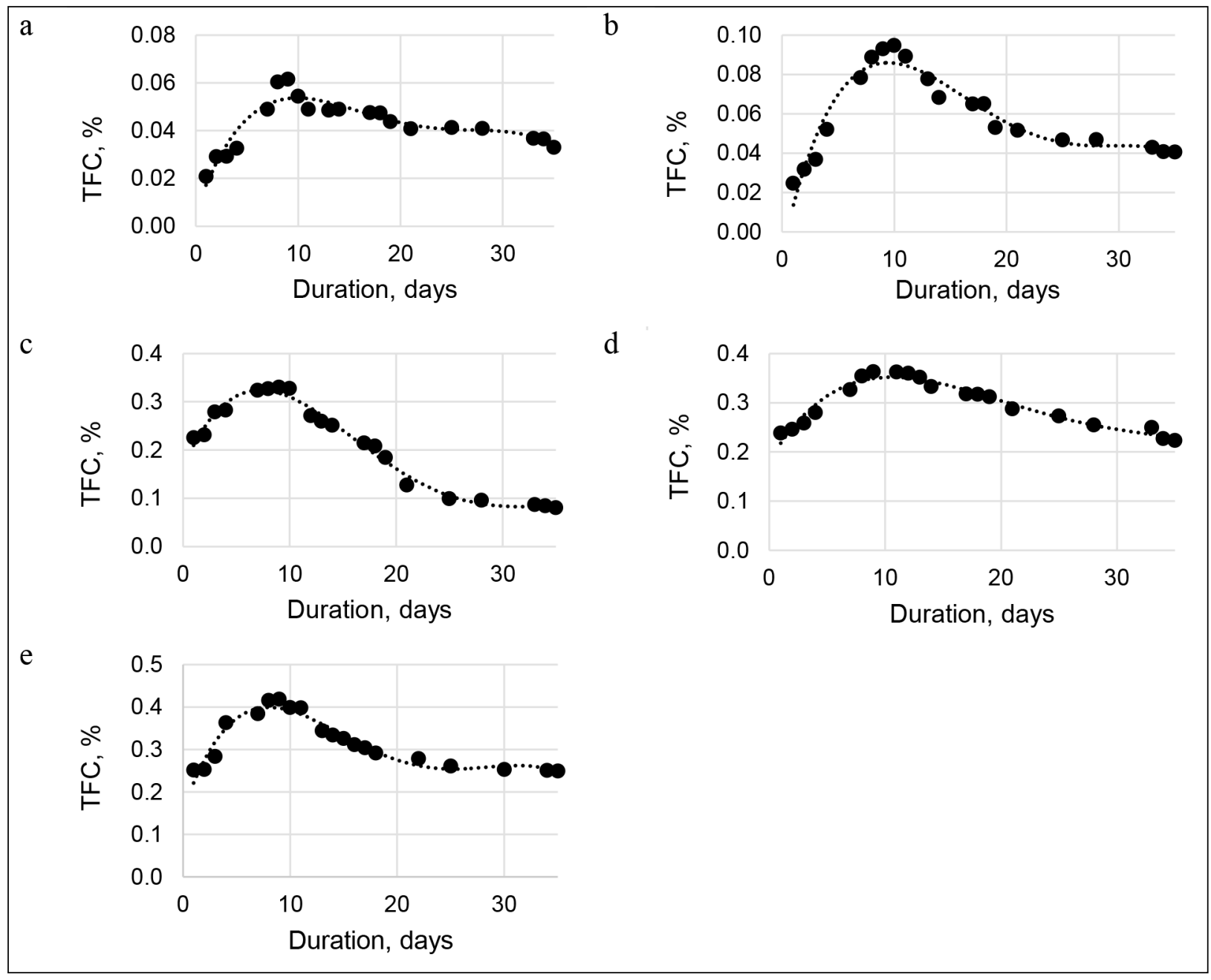

Fig. 3. TFC dependence on the process duration by using dried minced berries (harvested in 2017) poured out with AES (\%): $a-50, b-60$, $c-70, d-80, e-96$

speed is maintained), both stirrers were tested and the obtained results were compared (Table). Extracts were made from dried minced berries (collected in 2017) and different concentrations of aqueous ethanol solutions.

Initially, a duration of $30 \mathrm{~min}$ was chosen for stirring the extracts. The results confirmed the earlier conclusion that when the ethanol concentration increases, TFC increases too. It has also been observed that the total concentration of flavonoids by stirring with a magnetic stirrer in all cases is higher than that by stirring with a propeller stirrer. To find out if the TFC will increase with increasing stirring time, it is decided to stir the extracts for $60 \mathrm{~min}$. From the data provided, it can be seen that with the longer stirring time (from $30 \mathrm{~min}$ to $60 \mathrm{~min}$ ) TFC almost doubled. It has also been found again that better results are obtained by mixing with a magnetic stirrer than with a propeller one and using higher concentrations of aqueous ethanol solutions.

Extending the stirring time to 90 minutes a significant increase in the total flavonoid concentration has not been noticed compared to the stirring of extracts for $60 \mathrm{~min}$. Therefore, it was considered that more extension of the stirring time is inexpedient.

The data in the Table show that in all cases the highest TFC (0.304-0.498\%) was obtained using $96 \%$ ethanol and extracts were stirred with a magnetic stirrer, the lowest value (0.040-0.074\%) was obtained using $50 \%$ aqueous ethanol solution and a propeller stirrer for stirring.

Since in the literature sources [6, 月] one of the most popular extraction methods is hot continuous extraction (Soxhlet extraction), therefore, this method was also used in this work (Fig. 4). Extracts were produced from dried minced 
Table. The influence of time and mixing of extraction and different solvent on the concentration of flavonoids

\begin{tabular}{|c|c|c|c|c|c|c|}
\hline \multirow{5}{*}{$\begin{array}{l}\text { Concentration of } \\
\text { ethanol, } \%\end{array}$} & \multicolumn{6}{|c|}{ Duration } \\
\hline & \multicolumn{6}{|c|}{$30 \mathrm{~min}$} \\
\hline & \multicolumn{6}{|c|}{ Stirrer } \\
\hline & \multicolumn{3}{|c|}{ Magnetic } & \multicolumn{3}{|c|}{ Propeller } \\
\hline & $\overline{\mathbf{X}}^{*}$ & $S_{x}^{2} \cdot 10^{6 * *}$ & $S_{x} \cdot 10^{6 * * *}$ & $\overline{\mathbf{X}}^{*}$ & $S_{x}^{2} \cdot 10^{6 * *}$ & $S_{x} \cdot 10^{6 * * *}$ \\
\hline 50 & 0.043 & 1.53 & 0.77 & 0.040 & 0.43 & 0.21 \\
\hline 60 & 0.050 & 2.71 & 1.35 & 0.048 & 0.04 & 0.02 \\
\hline 70 & 0.069 & 2.60 & 1.30 & 0.062 & 2.28 & 1.14 \\
\hline 80 & 0.155 & 0.10 & 0.01 & 0.151 & 0.32 & 0.16 \\
\hline 96 & 0.304 & 0.60 & 0.30 & 0.286 & 2.81 & 1.40 \\
\hline \multicolumn{7}{|c|}{$60 \min$} \\
\hline 50 & 0.074 & 3.31 & 1.66 & 0.071 & 0.57 & 0.28 \\
\hline 60 & 0.091 & 0.68 & 0.34 & 0.084 & 3.24 & 1.62 \\
\hline 70 & 0.126 & 1.53 & 0.77 & 0.118 & $0, .32$ & 0.16 \\
\hline 80 & 0.250 & 0.04 & 0.08 & 0.219 & 1.74 & 0,09 \\
\hline 96 & 0.492 & 1.32 & 0.66 & 0.488 & 1.39 & 0.69 \\
\hline \multicolumn{7}{|c|}{$90 \min$} \\
\hline 50 & 0.079 & 0.14 & 0.07 & 0.074 & 1.10 & 0.55 \\
\hline 60 & 0,095 & 0.32 & 0.16 & 0.087 & 1.53 & 0.77 \\
\hline 70 & 0,130 & 1.10 & 0.55 & 0.120 & 0.04 & 0.02 \\
\hline 80 & 0,254 & 0.14 & 0.07 & 0.223 & 0.11 & 0.05 \\
\hline 96 & 0,498 & 0.09 & 0.45 & 0.491 & 0.25 & 0.12 \\
\hline
\end{tabular}

${ }^{*} \bar{X}$ is the average concentration of flavonoids, \%; ${ }^{*} S_{x}{ }^{2}$ is the variance; ${ }^{* *} S_{x}$ is the standard deviation.

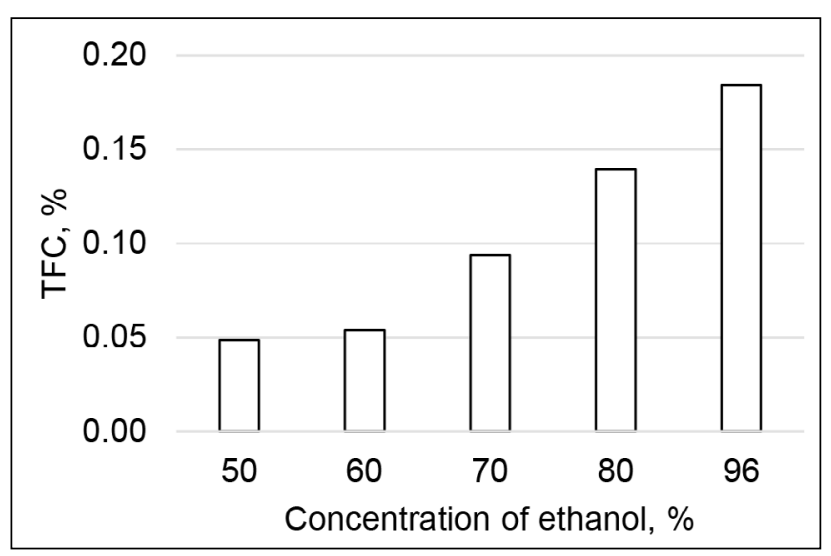

Fig. 4. TFC dependence on the AES concentration by using dried minced berries (collected in 2017) and the Soxhlet extractor

berries (collected in 2017) pouring with various concentrations of an aqueous ethanol solution.

Using the Soxhlet extractor, the extraction time is determined by the number of cycles, in this experiment it was 12 . Having analysed the results obtained by using the Soxhlet extractor, a di- rect dependence between ethanol concentration and total flavonoid concentration was noticed. The highest concentration was reached by using $96 \%$ ethanol (0.184\%), the lowest by using $50 \%$ AES (0.049\%).

As the TFC was not very large in these experiments, a more modern method of extraction - the ultrasonic bath - has been tested. In the extracts of berries collected in 2017 the influence of AES and extraction time on the total concentration of flavonoids was analysed and the obtained results are presented in Fig. 5 .

An analogous trend was noticed as by using other methods. When ethanol concentrations increase, the total concentration of flavonoids also increases. However, in this case, the maximum TFC is reached when the extraction time is $20 \mathrm{~min}$ and then begins to decrease. Using ultrasound for extraction, the water in the bath was not additionally heated. During the sonication, the temperature of the water (in the bath) and the extract 


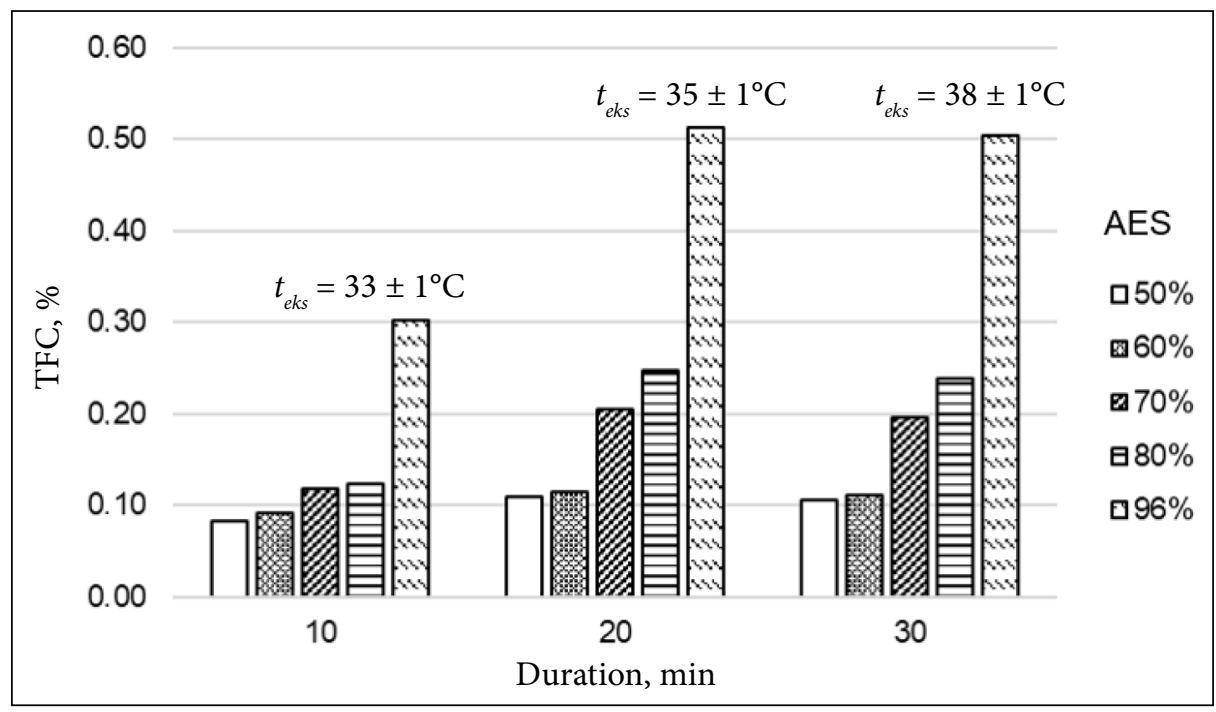

Fig. 5. TFC dependence on the process duration by using ultrasound on TFC extracts, which were produced with dried minced rowanberries (collected in 2017) and various AES concentration

(produced with 96\% ethanol) was measured to assess the changes in temperature and its impact on the results. Before the sonication, the temperature of the water and the extract was $24 \pm 1^{\circ} \mathrm{C}$, after $10 \mathrm{~min}$ of ultrasound extraction the temperature of the water was $21 \pm 1^{\circ} \mathrm{C}$ and the temperature of the extract $33 \pm 1^{\circ} \mathrm{C}$. Respectively, after 20 and $30 \mathrm{~min}$ the water temperature was $30 \pm 1^{\circ} \mathrm{C}$, and the temperature of the extract was $35 \pm 1^{\circ} \mathrm{C}$ and $38 \pm 1^{\circ} \mathrm{C}$. These data confirm the classical thermal theory of molecular motion. From the graph above (Fig. 5) the data show that the highest total concentration of flavonoids $(0.512 \%)$ was reached by using $96 \%$ ethanol and the duration of extraction was $20 \mathrm{~min}$.

Having summarised the results, it can be stated that the most appropriate method to produce extracts of rowanberries is by using an ultrasonic bath as the highest concentration of flavonoids $(0.512 \%)$ was reached in the shortest time (20 min). Due to the high content of these berries, the relatively simple method of extraction and the anti-inflammatory, antioxidant and antimicrobial flavonoids' effect [1, 2, 4, 5] such extracts of rowanberries can be used to produce tonics, antibacterial bandages and tinctures.

\section{CONCLUSIONS}

1. Regardless of the method used for extraction (extraction under static conditions, extraction by stirring, Soxhlet extraction and sonication), when ethanol concentration increases, the total concentration of flavonoids also increases.

2 . In the extracts produced with rowanberries (collected in 2017) the highest and the similar numerical value of the concentration of total flavonoids was achieved in two cases: after $20 \mathrm{~min}$ of extraction in an ultrasound bath $(0.512 \%)$ and stirring the extract for $90 \mathrm{~min}$ with a magnetic stirrer $(0.498 \%)$. In both cases, $96 \%$ ethanol was used.

3 . The highest total concentration of flavonoids produced in the extracts under static conditions using 96\% AES and berries collected in 2018 was $0.525 \%$, in 2017 it was $0.418 \%$.

Received 23 April 2019 Accepted 8 May 2019

\section{References}

1. Z. Gudžinskas, Žalioji sveikatos versmè: vaistiniu augaly vadovas (Green Health Spring: A Guide to Medicinal Plants), Brentus, Kaunas (2012) [in Lithuanian].

2. O. Ragažinskienè, S. Rimkienė, V. Sasnauskas. Vaistiniu augalu enciklopedija (Encyclopedia of Medicinal Plants), Lututè, Kaunas (2005) [in Lithuanian].

3. O. Raspé, C. Findlay, A. L. Jacquemart, J. Ecol., 88(5), 910 (2000).

4. K. Obelevičius, S. Petkevičiūtè, E. Šeinauskienè, Prieskoniniu augaly ir ju vartojimo žinynas (Catalogue of Potherbs and Their Use), Lutute, Kaunas (2011) [in Lithuanian].

5. F. Aladedunye, B. Matthäus, Food Chem., 159, 273 (2014). 
6. A. Gupta, V. Kothari, Int. J. Appl. Nat. Sci. (IJANS), 1(1), 8 (2012).

7. V. Kothari, A. Gupta, M. Naraniwal, Extraction Methods for Preparation of Bioactive Plant Extracts: A Comparative Study, Lambert Academic Publishing, Saarbrücken (2012).

8. V. Vaškelienè, R. Šlinkšienè, Studentu moksliniai tyrimai 2017/2018: konferencijos pranešimu santraukos (Students' Scientific Research 2017/2018: Abstracts of Conference Papers), Vilnius (2018) [in Lithuanian].

9. V. Jakštas, Ph. D. Thesis, Lithuanian University of Health Sciences (2005).

10. U. Olsson, U. Engstrand, P. Rupšys, Statistiniai metodai: Sas ir Minitab (Statistical Methods: Sas and Minitab), Akademija (2007) [in Lithuanian].

11. T. W. Charpe, V. K. Rathod, Iran. J. Chem. Eng., 11(4), 21, (2014).

\section{Vaida Vaškelienė, Rasa Šlinkšienė}

\section{EKSTRAKCIJOS METODO IR SĄLYGŲ ITAKA FLAVONOIDŲ KONCENTRACIJAI ŠERMUKŠNIO UOGŲ EKSTRAKTUOSE}

Santrauka

Paprastasis šermukšnis (Sorbus aucuparia L.) yra medis arba krūmas, kuris dažniausiai auginamas kaip dekoratyvinis augalas, nors pasižymi gydomosiomis savybėmis. Paprastojo šermukšnio vaistine žaliava gali būti žiedai, vaisiai, lapai ar žievè.

Šviežiuose šermukšnių vaisiuose aptinkama iki $65,0 \mathrm{mg} / 100 \mathrm{ml}$ karotinoidų; 44,5-72,5 mg/100 ml vitamino C; $1,5-2,4 \mathrm{mg} / 100 \mathrm{ml}$ jodo; $0,6-1,6 \mathrm{mg} / 100 \mathrm{ml}$ vitamino E; 4,0-7,0 \% sacharidų; 0,13-2,1 \% flavonoidų (junginių, pasižyminčių vitamino P savybèmis); iki
3,0 \% sorbo rūgšties ir sorbito; 1,9-2,6 \% kitų organinių rūgščių; iki $0,45 \%$ raugų; eterinio aliejaus; fosfolipidų; mineralinių medžiagų [1-3].

Šiam moksliniam tiriamajam darbui atlikti paprastojo šermukšnio uogos buvo renkamos 2017 ir 2018 m. spalio pabaigoje po pirmųu šalnų. Uogos buvo renkamos Kauno r. Kačerginès miestelyje, nuo to paties medžio tos pačios šakos, kad uogose esančių veikliujų medžiagu koncentracijai nedarytų ittakos pašaliniai veiksniai (saulè, drègmès kiekis, dirvožemis, oro užterštumas ir kt.).

Ekstraktams gaminti buvo naudojamos šaldytos arba džiovintos, smulkintos arba nesmulkintos paprastojo šermukšnio uogos ir ịvairių koncentracijų etanolio vandeniniai tirpalai (50\%, $60 \%, 70 \%, 80 \%$ ir $96 \%$ ), santykiu 1:10. Šermukšnio uogos buvo džiovinamos konvekcinejje krosnelëje, palaikant $60{ }^{\circ} \mathrm{C}$ temperatūrą tol, kol drègmès kiekis uogose tapo pastovus ir siekè $8,4 \%$. Kita dalis šviežiu uogų buvo užšaldyta ir laikoma $-18{ }^{\circ} \mathrm{C}$ temperatūroje.

Naudojant skirtingus ekstraktų gamybos metodus (ekstrakcija statinemis sąlygomis, ekstrakcija maišant, Soksleto ekstraktoriumi ir ultragarso voneleje), nustatyta, kad visais atvejais didejant etanolio koncentracijai, didejja ir bendra flavonoidų koncentracija.

2017 m. rinktų šermukšnio uogų ekstraktuose didžiausia ir skaitine verte panaši bendra flavonoidų koncentracija pasiekta dviem atvejais: $20 \mathrm{~min}$. naudojant ultragarso vonelę $(0,512 \%)$ ir ekstraktą $90 \mathrm{~min}$. maišant magnetine maišykle $(0,498 \%)$. Abiem atvejais naudotas $96 \%$ etanolio vandeninis tirpalas.

Didžiausia bendra flavonoidų koncentracija 2018 m. rinktų uogų ekstraktuose, gautuose statinèmis ekstrakcijos sąlygomis, naudojant $96 \%$ etanolio vandeninị tirpalą, buvo 0,525 \%, $2017 \mathrm{~m}$. - 0,418 \%. 